\title{
A Survey of the Floristic Diversity of the National Park of Marahoué after the Armed Conflicts in Ivory Coast
}

\author{
Yao Sadaiou Sabas Barima*, Kouassi Apollinaire Kouakou, \\ Akoua Tamia Madeleine Kouakou, Yao Charles Sangne \\ Training and Research Unit in Environment, University Jean Lorougnon Guédé, Daloa, Ivory Coast \\ Email: "byssabas@gmail.com
}

Received 23 May 2016; accepted 11 July 2016; published 14 July 2016

Copyright (C) 2016 by authors and Scientific Research Publishing Inc.

This work is licensed under the Creative Commons Attribution International License (CC BY).

http://creativecommons.org/licenses/by/4.0/

(c) (i) Open Access

\begin{abstract}
Most of the Ivorian areas designated as protected were trickled in for various agricultural activities. For these last few decades, the situation worsened in Ivory Coast because these protected areas were not guarded during the armed conflict of the years 2002-2011. The objective of this study is to assess the condition in which the floristic diversity of the National park of Marahoué (NPM) is after the armed conflicts of the years 2000. To achieve our purpose, a sampling has been conducted along five transects that go through different environments: inner the park, the edge of the park and the non-domanial property. A $20 \times 20 \mathrm{~m}$ plot square has been settled in each of these environments along each transect and each one separated from one another by $200 \mathrm{~m}$. Four (4) other pilots plots of $20 \times 20 \mathrm{~m}$ have been built up inside the park, relatively in the protected areas. Regarding these surveys, 303 plant species have been identified among which the most important are Fabaceae (6.27\%), Euphorbiaceae (5.28\%) and Rubiaceae $(5.28 \%)$ families. Twenty-four (24) species have a particular status according to the International Union for the Nature Conservation among which nineteen (19), and about $79.16 \%$ have been seen in the relatively protected areas. One of these species, Baphia Bancoensis Aubrév, is endemic in Ivory Coast. In the park, the agricultural activities have reduced the number of trees which diameter is over $30 \mathrm{~cm}$. Although the infiltration of clandestines in the NPM started long before the beginning of the conflicts, our work nevertheless permitted to point out them. During this period, these infiltrations were accelerated mainly because these people were looking for new lands to cultivate cocoas trees.
\end{abstract}

\section{Keywords}

Floristic Diversity, Conflicts, Anthropogenic Activities, Endemism, Ivory Coast

\footnotetext{
"Corresponding author.
}

How to cite this paper: Barima, Y. S. S., Kouakou, K. A., Kouakou, A. T. M., \& Sangne, Y. C. (2016). A Survey of the Floristic Diversity of the National Park of Marahoué after the Armed Conflicts in Ivory Coast. Open Journal of Forestry, 6, $259-268$. 


\section{Introduction}

The destruction of the world forest cover from 2005 to 2010 was estimated to $0.14 \%$ per year, but in the West Africa this deforestation rate was estimated to $0.46 \%$ (FAO, 2010). Notably in Ivory Coast, the deforestation represents a severe threat. Thus, the Ivorian forest surface which was estimated to 16 million hectares in 1900 (Chatelain et al., 2014), was reduced to 2.80 million in 2007 (FAO, 2007), which made of Ivory Coast one of the countries where the annual destruction rhythm is the highest in the world (Achard et al., 2002). The remaining forests are estimated to thousands hectares confined in forest reserves and National parks. It is on these latter that Ivory Coast has based its conservation and biodiversity policy on. Unfortunately, most of the protected areas are occupied for various anthropic activities (trees exploitation and agriculture, etc.). This situation has been widespread and stressed since the beginning of the politico-military conflict of the years 2000 which has driven to the missing of parks officials and the inefficiency of the government institution in these areas. These problems can be perceived through the management and the control of these protected areas driving mainly to the degradation of the forest cover and peculiarly to the one of the National park of Marahoué (NPM).

In fact, being the most important protected areas of Ivory Coast that is located in the connection forest-savannah area, the National park of Marahoué (NPM) has been threatening for several years due to the expanding agriculture and clearing trees, camps and villages' settlements (Konan, 2009). The annual rate of deforestation in this park was estimated to 3000 hectares (N'da et al., 2008). This rate would have been increased because of the massive movement of populations who are fleeing the war or are seeking to fertile soils in this place.

Although many surveys were conducted to show the impact of the agricultural activities on the flora of the NPM (N'da et al., 2008), those tackling the condition in which its floristic diversity was after the armed conflicts, did not exist. Therefore, the objective of this study is to assess the state of the floristic diversity of the park after a decade of political and military conflicts in Ivory Coast. In fact, our work has consisted on the one hand to compare the floristic diversity and on the other hand to analyze the structure of the vegetation in three types of areas going from the protected area to the non-domanial property without forgetting the intermediate place between both. A comparison made with pilots sites has permitted to figure out what the evolution of the calculated floristic parameters means.

\section{Analysis Device}

\subsection{Site of Investigation}

With a total surface of 101 thousand hectares (Lauginie, 2007), the National park of Marahoué (NPM) is located in Centre-West of Ivory Coast at $350 \mathrm{~km}$ from Abidjan in the direction from North to west on the route Bouaflé to Daloa (Figure 1). It was designated as a National park by the year 1968. The NPM is also situated in the Guinean mesosphere sector, in a climatic transition area with the South part damper than the North one. The annual average temperature varies between $25^{\circ} \mathrm{C}$ and $28^{\circ} \mathrm{C}$ (Eldin, 1971). The River of Bandaman, which sets the bounds of the park to the West and the North, is the main hydrographic network provider. Considered as one of the last remnants of natural formations of the contact forest-savannah, it was covered, over $75 \%$ of its surface, with semi-decidue dense damp forests in its West side and dry forests in the North-East; the open savannahs with caught in forest galleries, occupied $25 \%$ of the surface in the East (Konan, 2009).

Thanks to these two types of vegetation, the faunas of the forests and those of the savannahs were side by side (elephants, buffaloes, duikers, hartebeests, the cob of Buffon, monkeys, mongooses, etc.) We also noticed the living of endemic and endangered species such as the smoked mangabey, the Southern Festoon Guenon, colobus, but we have also some disappearing species like Chimpanzee (IUCN, 2008). Since the 1970's, the park is confronted with a heavily anthropic pressure precisely by the agricultural clearances. The increase in the demand for fertile land for crops of speculation (coffee, cocoa) has resulted in a land saturation and the infiltration of more and more important clandestine in the park (N'da et al., 2008). This investigation has been conducted only in the west side of the park.

\subsection{Sampling Drawing and Data Collection}

There are many types of vegetation in the NPM: crops (mainly cocoa trees), fallows and a few remnants forests. In order to compare the diversity of the plants in the different habitats, some evaluations of the floras were made in using two methods: the sampling area and the sampling itinerant analyses. The sampling area consisted in 


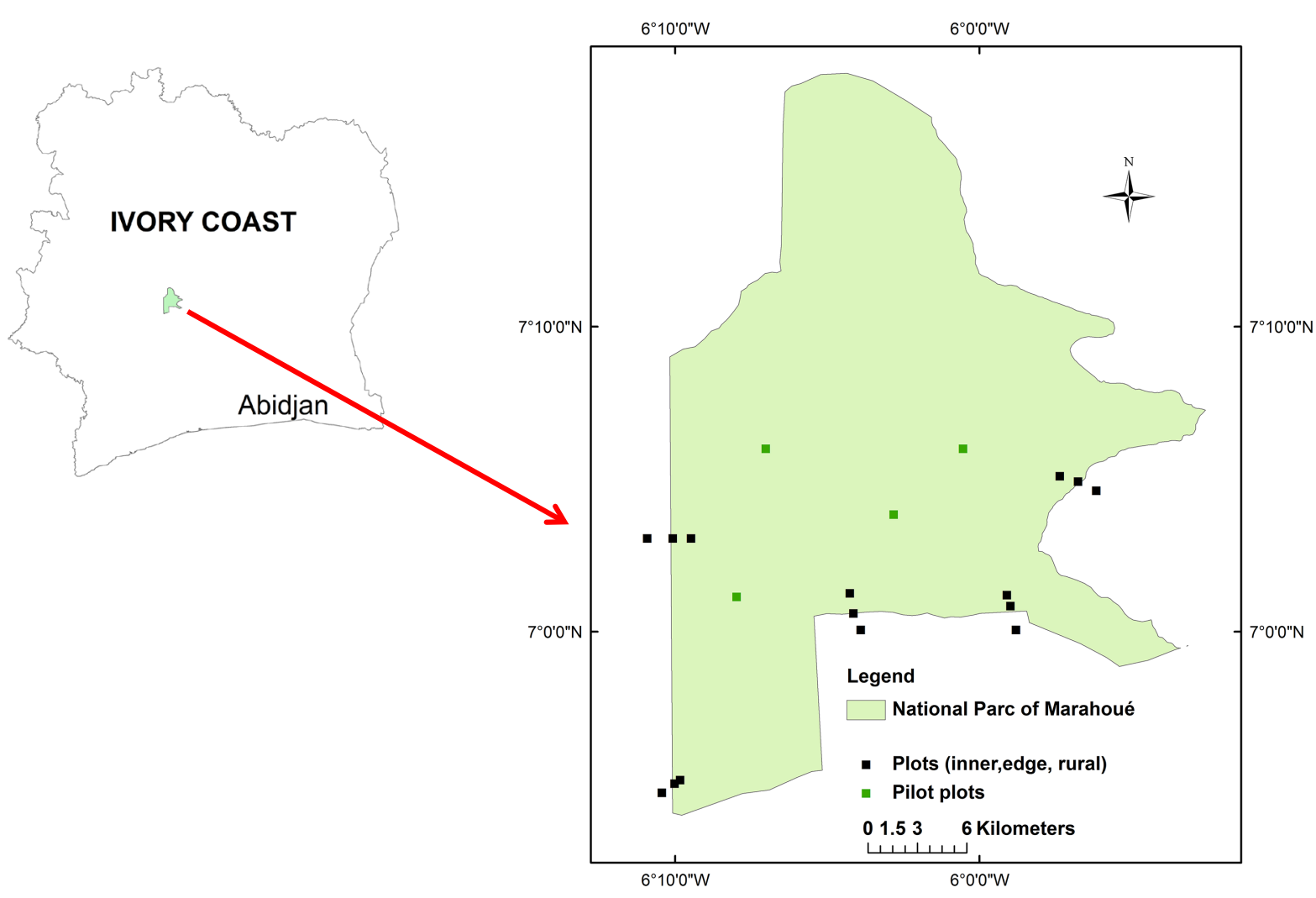

Figure 1. Location of National Park of Marahoué in Ivory Coast and spatial distribution of sampling sites.

delimiting the plots of $20 \mathrm{~m} \times 20 \mathrm{~m}$ in which all the plant species have already been identified. Plant species were identified directly on the sites by a taxonomist. Those who have not been identified at the sites have been identified in the herbarium of the National Centre of Floristic (CNF) of the University Félix Houphouët-Boigny (Ivory Coast). The circumferences of all the trees or shrubs whose diameter at breast heigh are superior or equal to $10 \mathrm{~cm}$ were measured with a ribbon meter. The measures have been taken in $30 \mathrm{~cm}$ over the buttresses for thereof species. These measures allowed us to evaluate the distribution of stems per small plot. Some sampling itinerants have also been realized between plots along the transect and have concerned only with the species uncollected in the plots (Figure 2). These species have also permitted to complete the general floristic list. As result, 5 transects have been settled in the different sides of the Park (Figure 2), each of them goes from the interior of the non-domanial area (rural area) to the edge of the area. A square plot of $20 \times 20 \mathrm{~m}$ has been settled on each site along the transect and separated one to another by $200 \mathrm{~m}$. Four pilots' plots of $20 \times 20 \mathrm{~m}$ have been fixed in the most protected areas of the park. It relates to the vegetation that existed before the armed conflicts in Ivory Coast, observable on the old maps of the soils occupied. As a result, the investigations have been conducted in five transects of $460 \mathrm{~m}$ long each and composed of $400 \mathrm{~m}^{2}$ plots each and four pilots' plots of $20 \mathrm{~m} \times$ $20 \mathrm{~m}$ each.

\subsection{Analysis of Data}

The numbers of species, families and morphological types (trees, shrubs, lianas, and grasses) have been specified in each area. These parameters allowed us to have a global idea of the floristic composition. In order to compare the variety of the different places, the index of diversity by Shannon and Weaver (1948) and the one of equitability by Pielou (1966) have been calculated. In combining the number of species and their relative abundance, the index by Shannon and Weaver has permitted to assess the species that the settlements are made of. The value of this index varies from 0 (a single specie or the one which is dominant over the others) to $\log \mathrm{S}$ (when all the species have the same abundance) and is obtained from the following formula: 

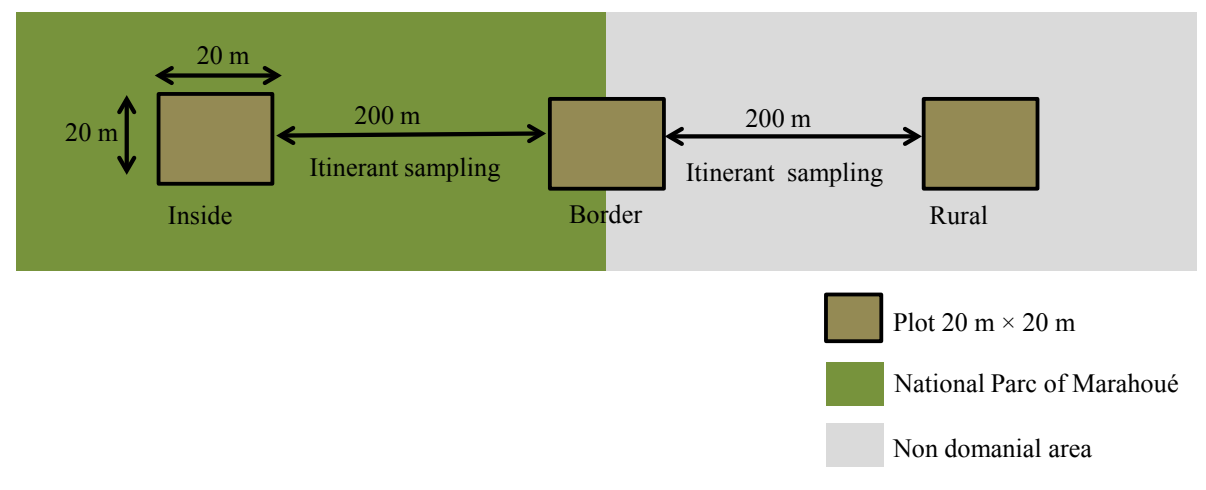

Figure 2. Sampling design.

$$
\mathrm{H}=-\Sigma\left(\frac{\mathrm{ni}}{\mathrm{N}}\right) \times \ln \left(\frac{\mathrm{ni}}{\mathrm{N}}\right)
$$

With $\mathrm{N}=$ total size of $\mathrm{S}$ species counted, $\mathrm{ni}=$ the size of individuals of a i species. The calculation of this index of diversity is added to the one of equitability by Pielou (E) which represents the ratio of $\mathrm{H}$ to the theoretical and maximum diversity in the settlement $(\log \mathrm{S})$ :

$$
\mathrm{E}=\frac{\mathrm{H}}{\log 2 \mathrm{~S}}
$$

This index varies from 0 to 1 . The more the $\mathrm{E}$ value is near to 1 , the more the considered area species are divided up equally between the individuals that compose them, but the weak values correspond to the presence of a number of rare species or of small number of dominant species (Pielou, 1966).

The degree of resemblance between the different areas was evaluated from the coefficient of the similitude of Sorensen (Cs). It was obtained by this mathematic formula:

$$
\mathrm{Cs}=\frac{100 \times 2 \mathrm{c}}{\mathrm{a}+\mathrm{b}}
$$

With $\mathrm{a}=$ number of species in the area $\mathrm{A} ; \mathrm{b}=$ number of species in the area $\mathrm{B} ; \mathrm{c}=$ number of common species in both ecologic areas. The more the lists have species in common, the more Cs tends toward $100 \%$. The more both floristic lists are different, the more the Cs value tends toward 0 .

The qualitative diversity of the species was also determined by counting the number of species that are identified in the difference areas. It was to identify the Ivorian endemic species (GCi), the endemic of forests of the Upper Guinea (UG), or from the west African (GCW) forest's, on the basis of the pre-established lists of species by Aké-Assi $(2001 ;$ 2002). These lists were completed with the one of the rare and endangered species of the Ivoirian's flora according to the list published by the International Union for the Nature Conservation (IUNC, 2015).

The comparison of the different habitats was also about the distribution of some stems per group of diameter in different areas. This distribution has permitted to assess the situation of plant communities and to know how they can put out naturally in different areas.

\section{Results}

\subsection{Variety and Composition of the Flora}

This study has permitted to enumerate 303 plant species that are shared out among 223 genera and 73 families out of which the most important are Fabaceae (6.27\%), Euphorbiaceae (5.28\%) and Rubiaceae (5.28\%). The pilot area and the edge with respectively 162 and 84 species possess the richest floras. Inside the park they are observed with 74 other species. The rural area contains few species (Table 1). Among all these plants, trees and shrubs are more numerous in the pilot area than in the other areas (inside, border, rural). In each area trees and shrubs constitute over $50 \%$ of species (Table 1 ). The herbaceous species are least represented in the different areas (Table 1). Considering only sampling areas, the values of the index by Shannon and Weaver vary from 
4.29 in the rural area to 5.11 in the pilot areas of the park (Table 2). These values are more or less close to one another and the highest one is found in the pilot area showing that this environment possesses more diversified species than the others. The values of equitability vary from 0.96 to 0.98 and tend to 1 , suggesting that the individual species are equally divided up in the different areas.

\subsection{Floristic Resemblance between Different Types of Areas}

After enumerating all the species, we notice that all those that are either inside or to the edge of the park have 30 plant species in common with a likeness coefficient of about $40.54 \%$. Both areas have respectively the same floristic species of $43.61 \%$ and $42.03 \%$ with the rural area. Less than $20 \%$ of those counted species in both areas are encountered in the pilot area (Table 3). The rural and pilot areas have 18 species in common which represent $33.64 \%$ of inventoried species in these two types of areas. Twenty-seven (27) common species have been enumerated in all the three (3) investigated areas and those that are generally cultivated are: Theobroma cacao Linn., Manihot esculenta Crantz., Ananas comosus (L.) Merr., Musa paradisiacal Linn., Xanthosoma mafaffa Schott.

As a result, 24 species with a particular status have been collected in the different areas (Table 4), about $0.79 \%$ of all the enumerated species. Nineteen (19) of these species are inventoried in the pilot areas, either $79.16 \%$ of all the species with particular species. Only a single Ivorian endemic species (GCi), Baphiabancoensis Aubrév, has been encountered in the pilot area. Fifteen (15) endemic species of West-African forest bloc (GCW) have been counted among which twelve (12), about $80 \%$ of GCW, have been inventoried in the pilot area and three $(20 \%$ of GCW) in each of the three areas (inside, border, and rural). Twelve (12) of these species with a particular species are registered on the red list of the IUCN (Table 4). Among these species, eight (8) are

\begin{tabular}{cccccc} 
Table 1. Richness and floristic composition in area types. & \multirow{2}{*}{ Total } \\
\cline { 2 - 5 } & \multicolumn{5}{c}{ Types of area } \\
\cline { 2 - 5 } & Inside & Border & Rural area & Pilot & \\
\hline Number of species & 74.00 & 84.00 & 71.00 & 162 & 302 \\
Number of families & 41.00 & 43.00 & 34.00 & 56.00 & 73.00 \\
Trees species (\%) & 53.52 & 59.75 & 57.57 & 60.63 & 60.61 \\
Lianas species (\%) & 28.17 & 24.39 & 22.73 & 34.37 & 27.94 \\
Grass species (\%) & 18.31 & 15.85 & 19.69 & 05.00 & 11.45 \\
\hline
\end{tabular}

Table 2. Values of diversity indexes in different types of area.

\begin{tabular}{ccccc}
\hline & \multicolumn{4}{c}{ Types of area } \\
\cline { 2 - 5 } & Inside & Border & Rural & pilot \\
\hline Shannon and Weaver & 4.15 & 4.49 & 4.17 & 5.11 \\
Equitability & 0.96 & 0.97 & 0.97 & 0.98 \\
\hline
\end{tabular}

Table 3. Similitude coefficients (percentage) of Sørensen, 1948 (in bold) and number of common species in two types of areas.

\begin{tabular}{ccccc}
\hline Areas & Inside & Border & Rural area & Pilot \\
\hline Inside & - & 40.54 & 43.61 & 17.19 \\
Border & 30 & - & 42.03 & 19.59 \\
Rural area & 29 & 33 & - & 33.64 \\
Pilot & 19 & 24 & 18 & - \\
\hline
\end{tabular}


Table 4. Species with a particular status inventoried in the different areas. 0 = absence; 1 = presence; GCi: endemic to Ivorian flora; GCW: West African forest bloc; HG: Upper Guinea; R: Rare; LR: weak risk; dR: become rare; VU: vulnerable; IUNC $=$ International Union for Nature Conservation.

\begin{tabular}{|c|c|c|c|c|c|c|}
\hline Species & Endemism level & Statu IUCN & Inside & Border & Rural area & Pilot \\
\hline Baphiabancoensis & $\mathrm{GCi}$ & - & 0 & 0 & 0 & 1 \\
\hline Caloncoba echinata & GCW & - & 0 & 1 & 0 & 0 \\
\hline Cola caricaefolia & GCW & $\mathrm{R}$ & 0 & 0 & 0 & 1 \\
\hline Combretum grandiflorum & GCW & & 0 & 0 & 0 & 1 \\
\hline Combretum zenkeri & - & $\mathrm{R}$ & 0 & 0 & 0 & 0 \\
\hline Crossostema laurifolium & GCW & $\mathrm{R}$ & 0 & 1 & 0 & 1 \\
\hline Cynanchum adalinae & GCW & - & 1 & 0 & 1 & 0 \\
\hline Dalbergia oblongifolia & GCW & - & 0 & 0 & 1 & 1 \\
\hline Dialum guineense & - & $\mathrm{R}$ & 0 & 0 & 0 & 1 \\
\hline Dioscorea burkilliana & GCW & - & 0 & 0 & 0 & 1 \\
\hline Diospyros cooperi & GCW & - & 0 & 0 & 0 & 1 \\
\hline Dracaena ovata & - & $\mathrm{R}$ & 0 & 0 & 0 & 1 \\
\hline Entandrophragma utile & - & VU & 0 & 0 & 0 & 1 \\
\hline Euadeniaeminens & GCW & $\mathrm{dR}$ & 1 & 0 & 0 & 1 \\
\hline Guarealeonensis & GCW & - & 1 & 1 & 0 & 1 \\
\hline Hymenostegiaau brevillei & GCW & - & 0 & 0 & 0 & 1 \\
\hline Milicia excelsa & - & LR & 0 & 0 & 0 & 1 \\
\hline Milicia regia & GCW, HG & $\mathrm{R}$ & 0 & 0 & 0 & 1 \\
\hline Nesogordoniapapaverifera & - & VU & 1 & 1 & 0 & 1 \\
\hline Strychnos cuminodora & GCW & - & 0 & 0 & 0 & 1 \\
\hline Tiliacora dinklagei & GCW & - & 0 & 0 & 0 & 1 \\
\hline Triclisiapatens & GCW & - & 0 & 0 & 1 & 0 \\
\hline Triplochiton scleroxylon & - & LR & 0 & 1 & 0 & 0 \\
\hline Turraea heterophylla & - & $\mathrm{R}$ & 1 & 0 & 0 & 1 \\
\hline
\end{tabular}

rare "R" and one (1) has become rare "dR". These species are encountered only in the pilot area (here are some examples: Cola caricaefolia (G. Don) K. Schum., Crossostemma laurifolium Planch. Ex Benth, Euadeniaeminens Hook. F., Dracaena ovate Ker Gaw.) (Table 4). Two of these species are vulnerable like Entandrophragma utile (Dawe \& Sprague) Sprague and Nesogordoniapapaverifera (A. Chev.) R. Capuron and are encountered only in the pilot area.

\subsection{Diametrical Structure of the Vegetation of the Areas}

In all the three investigated areas, the stems with diameters inferior to $30 \mathrm{~cm}$ are more numerous (Figure 3 ) and constitute over $50 \%$ of plantings. The relatively protected areas (pilot) have more stems than the other areas. In this area, declining evolution of the stems with small diameters (10 to 20) to those with the greatest diameters (90 to 100) is observed, giving the final curve, an inverted "J" form (Figure 3$)$. The greatest diameters $(30 \mathrm{~cm})$ are almost absent in the other areas (Figure 3). 


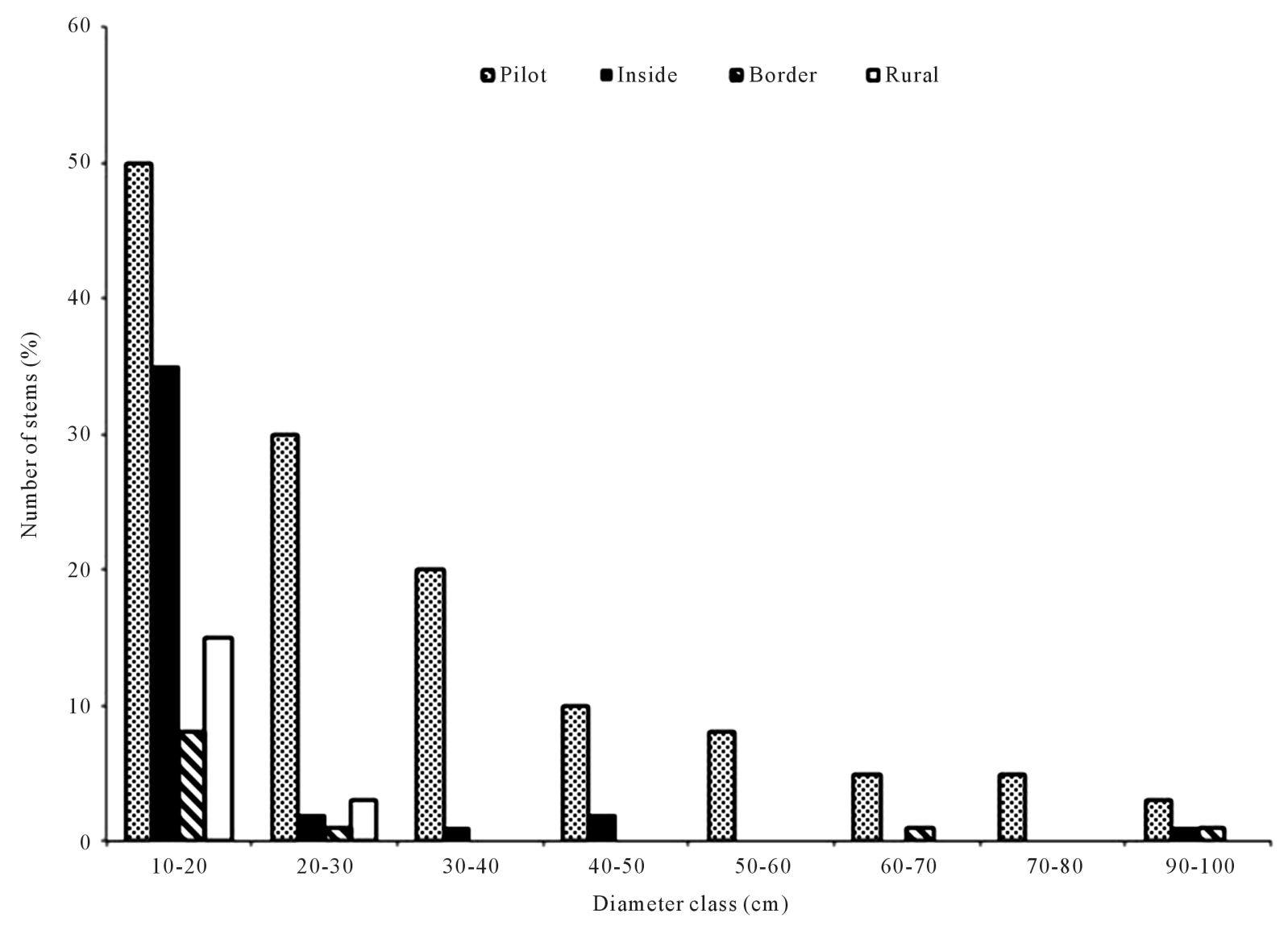

Figure 3. Stem distribution by diameter classes in areas.

\section{Discussion}

This survey has permitted to obtain 303 plantspecies divided up between 223 genera and 73 families whose most important are the Fabaceae (6.27\%); Euphorbiaceae (5.28\%) and the Rubiaceae (5.28\%). These values represent $49.92 \%$ of the whole flora of NPM, that is to say $55.47 \%$ in genera and $76.84 \%$ in families. In fact, N'da et al. (2008), in the whole park had obtained 607 plantspecies dispatch into 402 genera and 95 families whose most important were the Fabaceae and the Rubiaceae.

The pilot areas which constitutes the remains of the park possess the richest and the most diversify flora compared with the others area. Into the park, trees and shrubs are numerous; this would express the logical conditions of a protected forest (Ouattara et al., 2003). On the contrary, the large presence of tree species in the non-domanial area and the edge comparatively inside the park would show a flora reconstruction in progress in these areas. This fact may be the result of an intensive human activities in the park compared with the non-domanial area. In fact, the increase of the need in fertile soil for speculation crops (coffee, cocoa) in the last decade has provoked an overcrowded landed property trouble in the surrounding and a massive infiltration of clandestines in the NMP (Konan, 2009). Then the crops (cocoa and coffee) becoming obsolete (Figure 4) in the non-domanial area, the only issue for farmers is to go and settle down inside the park. The fallows in the non-domanial area are not required by the populations who prefer the uncultivated area of the park.

Then these non-domanial areas become the old fallows lands relatively rich with tree species. The age of the orchards of some cocoa trees inside the park being over 15 years old (Figure 5), prove that the infiltration did not begin with the armed conflicts period in Ivory Coast (2002-2011) contrary to what has been seen in the neighboring protected areas, the classified forest of the High-Sassandra (Kouakou et al., 2015).

However, the infiltration in the NPM has surely increased due to the massive movement of populations in 2002 (N'da et al., 2008) during the armed conflicts in Ivory Coast. Indeed, during this period, the Ivorian government was not able to set up a protective forests policy, thus favouring the anarchical or illegal occupation of 


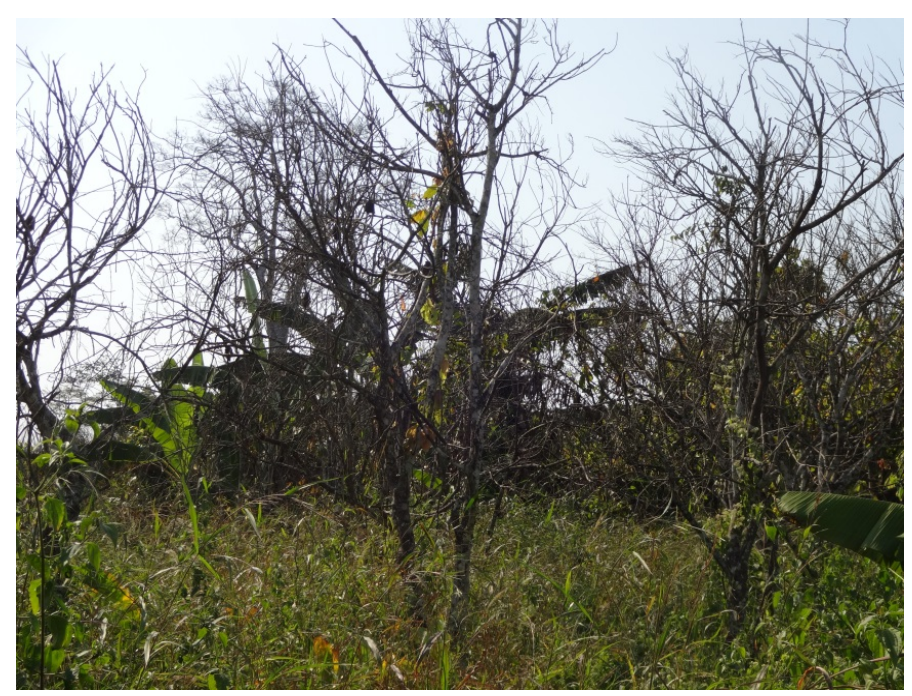

Figure 4. Old farm cocoa observed at the periphery of the NPM Marahoué.

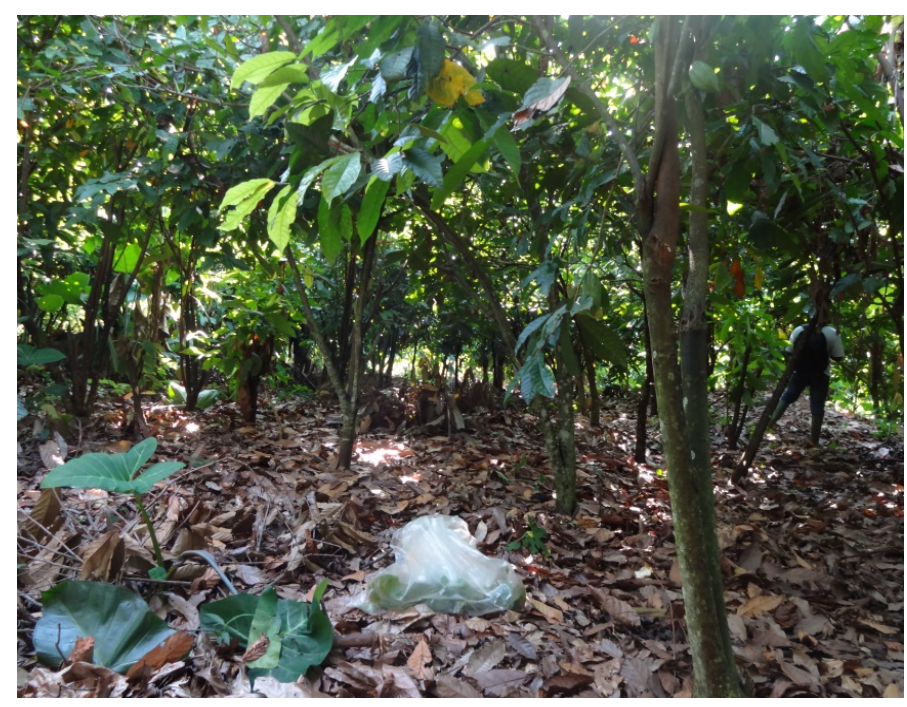

Figure 5. Cocoa crops (over 15 years) in the NPM.

the protected areas (Kouakou et al., 2015). This dysfunction has favoured the creation of many cocoa trees plantations inside the park. Among these cocoa trees, some are aged between nine (9) and ten (10) years old.

According to Guillaumet and Adjanohoun (1971), the huge penetration of the sunlight into the forests caused by human activities could favour the disappearance of lianas. In fact, the ratio of lianas is weaker inside, to the border and in the rural area in comparison with the pilot areas. This fact could be explained by the intensive agricultural activities based only on cocoa and coffee trees cultures done inside the rural area. The farmers when clearing proceed by a systematic cut of all the species, trees, lianas, grass that could prevent the growing of cultivated plants.

Yet, the presence of a few types of lianas in the areas justifies their large potentialities of regeneration and the adaptation to shadow made by cocoa and coffee trees (Ouattara et al., 2013). The different similitude coefficients values obtained shows a difference of flora in the area types. However, some similitudes exist among the three areas (inside, border and rural area) where 27 common species subsist. Most of the common plants are those cultivated and they show the similarity of agricultural activities that take place as well in the rural area as inside the park. Indeed, the farmers and the illegal immigrants practice cocoa-culture as main activity. The cocoa-culture is associated with the subsistence ones (banana, yam, taro, cassava, maize) during the first years. 
According to N'Guessan (2010), during the two first years, the subsistence cultures protect small plants of income cultures against the sunlight. After these two years, the farmers favour the cocoa-cultures in aid of the subsistence ones. Then these subsistence cultures that are cultivated in different areas attest the practice of the subsistence agriculture in three analyzed areas (inside, border, rural).

Most of the species with a peculiar status that have been enumerated in different areas have already been seen in the pilot area (Table 4). This area being well protected, it could favour the proliferation of particular species like the Ivorian endemic specie Baphiabancoensis. For Tchouto (2004), the species with peculiar status are the most sensitive to the disturbances caused by human-being. And also for Van Gemerden (2004), human activities that take place as well inside the park or around do not favour the proliferation of species with peculiar status. Though, we notice the presence of some particular species in the crops. This is due to the fact that the peasants domesticate some plants for many reasons or they use them as shadow to protect the young cocoa plants against the sunlight (Kouakou et al., 2015).

The stems categorized according their diameter in the different areas are unequally distributed. The distribution of the stems in the pilot area has an "inverted J" shape which is the peculiar characteristic of the tropical forests (Kouamé, 1998). It also shows that the youngest trees with small diameters are numerous than the ones with great diameters (Adou et al., 2015). Furthermore, the absence of the categories with diameters superior to $30 \mathrm{~cm}$ in the other areas show again the agricultural activities in the park, mainly the cocoa culture as said above. In fact, the growing and the development of the tree species are regularly interrupted during the weeding of the crops. The peasants also prefer keeping only the useful plants in their crops. Therefore the agricultural activities in the park have greatly caused the disappearance of the biodiversity whose existence is only factitious.

\section{Conclusion}

This study has permitted to assess the condition in which the current varieties of the flora in the west side of the National park of Marahoué are after the armed conflicts in Ivory Coast. This investigation shows that the massive infiltrations of the populations in the park in searching for fertile soil and the absence of park officials have intensified the degradation of this protected area. Despite this threatening, twenty four (24) species with peculiar status have been categorized, about $77.19 \%$ (19 species) in forests relics inner the park. A great number of tree species have been collected as well in underneath pressure areas as in those which were relatively kept denoting a possible rebuilding of the flora of the park if only the anthropic pressure blurred out. Though the agricultural practices have greatly reduced the number of trees with more than $30 \mathrm{~cm}$ in the park, before this challenge of ensuring the preservation of the biodiversity and the necessity to enable a lasting development, it would be important to reinforce some projects of sensitization and then educate the illegal immigrants and the riparians who occupy the park on the necessity to preserve the biodiversity. Creating new activities opportunities in ecotourism could facilitate the redeployment of these illegal immigrants who live in the park to more legal activities.

\section{Acknowledgements}

The present study has been carried out in the framework of the project GEOFORAFRI financed by the "Fonds Français pour l'Environnement Mondial" (FFEM) with the technical support of "Institut de Research pour le Développement" (IRD). It has also been supported by "Académie des Sciences, des Arts, des Cultures d'Afrique et des Diasporas Africaines" (ASCAD, Ivory Coast) and The World Academy of Sciences (TWAS). This study was possible thanks to the "Office Ivoirien des Parcset Réserves" (OIPR) who authorized access to the park".

\section{References}

Achard, F., Eva, H. D., Stibig, H. J., Mayaux, P., Gallego, J., Richards, T., \& Malingreau, J. P. (2002). Determination of Deforestation Rates of the World's Humid Tropical Forests. Science, 297, 999-1002. http://dx.doi.org/10.1126/science.1070656

Adou, Y. C., Blom, E. C., Dengueadhé, K. T. S., Van, R. S. A. R., N'guessan, K. E., Wittebolle, G., \& Bongers, F. (2005). Floristic Diversity and Vegetation in the Tai National Park, Ivory Coast. Tropenbos International et ECOSYN, $1566-6492$.

Aké-Assi, L. (2001). Flora of Ivory Coast 1, Catalog, Systematics, Biogeography and Ecology. Geneva, Switzerland: Conservatoire et Jardin Botanique de Genève.

Aké-Assi, L. (2002). Flora of Ivory Coast 2, Catalog, Systematics, Biogeography and Ecology. Geneva, Switzerland: Conservatoire et Jardin Botanique de Genève. 
Chatelain, C., Dao, H., Gautier, L., \& Spichiger, R. (2004). Forest Cover Changes in Côte d'Ivoire and Upper Guinea. In L. Poorter, F. Bongers, N. F. Kouamé, \& W. D. Hawthorne (Eds.), Biodiversity of West Africa Forests, an Ecological Atlas of Woody plants Species (p. 15), Cambridge, UK: Cabipublishing. http://dx.doi.org/10.1079/9780851997346.0015

Eldin, M. (1971). Le climat de la Côte d'Ivoire. In Le milieu naturel de Côte d'Ivoire, Mémoire ORSTOM (pp. 73-108), Paris: ORSTOM. http://www.documentation.ird.fr/hor/fdi:16372

FAO (2007). State of the World's Forests 2007. Rome: Food and Agriculture Organization of the United Nations. www.fao.org/docrep/009/a0773e/a0773e00.htm

FAO (2010). Global Forest Resources Assessment 2010. Rome: FAO Forestry Paper No. 163. www.fao.org/docrep/013/i1757f/i1757f.pdf

Guillaumet, J. L., \& Adjanohoun, E. (1971). The Natural Environment of the Ivory Coast. In Mémoire ORSTOM (pp. 161-263), Paris, France: ORSTOM. http://www.documentation.ird.fr/hor/fdi:16372

IUCN (2008). Evaluation of Effectiveness of Management of Protected Areas: Parks and Reserves of Côte d'Ivoire.

IUCN (2015). IUCN Redlist of Threatened Species. Version 2015.1 www.iucnredlist.org

Konan, K. E. (2009). Diagnosis-Analysis of the Human Environment of the National Park Marahoué. Géographie Tropicale et d'Environnement, 1, 1-11.

Kouakou, K. A., Barima, Y. S. S., Kouakou, A. T. M., Sangne, Y. S., Bamba, I., \& Kouamé, N. F. (2015). Armed Post-Conflict Plant Diversity of the Classified Forest of Haut-Sassandra (Central West of Ivory Coast). Journal of Animal \& Plant Sciences, 26, 4058-4071.

Kouamé, F. N. (1998). Influence of Logging on Vegetation and Flora of the Classified Forest of Haut-Sassandra (Central West of Ivory Coast). PhD Thesis, Ivory Coast, Université de Cocody-Abidjan.

Lauginie, F. (2007). Nature Conservation and Protected Areas in Ivory Coast. Abidjan: NEI/Hachette et Afrique Nature.

N'da, D. H., Adou, Y. C. Y., N'Guessan, K. E., Moussa Koné, M., \& Sangne, Y. C. (2008). Analysis of the Floristic Diversity of the Marahoue National Park, Center-West of Côte d'Ivoire. Afrique Science, 4, 552-579.

N'da, D. H., N'Guessan, K. E., Wajda, E. M., \& Affian, K. (2008). Apport de la télédétection au suivi de la déforestation dans le Parc National de la Marahoué (Côte d'Ivoire). Revue Télédétection, 1, 17-34.

N'Guessan, S. A. (2010). Evaluation of the National Forest Protection Policy of Ivory Coast from Geomatics Tools: Case of Marahoué National Park. PhD Thesis, Montréal: Université du Québec.

Ouattara, D., Vroh, B. T., Kpangui, K., \& N'Guessan, K. E. (2013). Plant Diversity and Conservation Value of the Botanical Reserve of Agbaou, Center-West of Ivory Coast. Journal of Animal \& Plant Sciences, 20, 3034-3047.

Pielou, E. C. (1966). The Measurement of Diversity in Different Types of Biological Collections. Journal of Theoritical Biology, 13, 131-144. http://dx.doi.org/10.1016/0022-5193(66)90013-0

Shannon, C. E., \& Weaver, W. (1948). A Mathematical Theory of Communication. Bell System Technical Journal, 27, $379-$ 423. http://dx.doi.org/10.1002/j.1538-7305.1948.tb01338.x

Sørensen, T. (1948). A Method of Etablishing Groups of Equal Amplitude in Plant Sociology Based on Similary of Species Content. Det Kongelige DanskeVidenskabernes Selskab. Biologiske Skrifter, 5, 1-34.

Tchouto, G. P. M. (2004). Plant Diversity in Central African Rainforest: Implication for Biodiversity Conservation in Cameroon. PhD Thesis, Department of Plant Sciences, Biosystematic Group, Wageningen: Wageningen University.

Van Gemerden, B. S. (2004). Disturbance, Diversity and Distributions in Central Africain Rainforest. PhD Thesis, Wageningen: Wageningen University. 


\section{Submit or recommend next manuscript to SCIRP and we will provide best service for you:}

Accepting pre-submission inquiries through Email, Facebook, LinkedIn, Twitter, etc.

A wide selection of journals (inclusive of 9 subjects, more than 200 journals)

Providing 24-hour high-quality service

User-friendly online submission system

Fair and swift peer-review system

Efficient typesetting and proofreading procedure

Display of the result of downloads and visits, as well as the number of cited articles

Maximum dissemination of your research work

Submit your manuscript at: http://papersubmission.scirp.org/ 